\title{
STUDIES ON THE FORMATION OF PEARLS. I. -ON THE RELATIONSHIPS OF PROTEINS AND CaCO3 CRYSTALS IN THE LAYER OF BAROQUE PEARLS-
}

\author{
$\operatorname{AUTHOR}(\mathrm{S})$ :
}

Matsui, Yoshiichi; Hirota, Takeo

\section{CITATION:}

Matsui, Yoshiichi ...[et al]. STUDIES ON THE FORMATION OF PEARLS. I. -ON THE RELATIONSHIPS OF PROTEINS AND CaCO3 CRYSTALS IN THE LAYER OF BAROQUE

PEARLS-. PUBLICATIONS OF THE SETO MARINE BIOLOGICAL LABORATORY 1952, 2(2): 331 339

\section{ISSUE DATE:}

1952-10-05

URL:

http://hdl.handle.net/2433/174671

RIGHT: 


\title{
STUDIES ON THE FORMATION OF PEARLS. I. ON THE RELATIONSHIPS OF PROTEINS AND $\mathrm{CaCO}_{3}$ CRYSTALS IN THE LAYER OF BAROQUE PEARLS*
}

\author{
YosHIICHI MATSUI \\ Nippon Institute for Scientific Research on Pearls \\ c/o Kyoto University \\ and. \\ TAKEO HIRO'TA \\ Zoological Institute, Kyoto University
}

With Plate XIII and 3 Text-figures

\section{INTRODUCTION}

On the formation of pearl layers, as well as on the mechanism of $\mathrm{Ca}$ deposition in the shells, there are still remain many problems unsolved.

We studied the abnormal structures which are often found in the culture pearls, in attempting to solve these problems.

As to material, we used the pearl named the "steel colored pearl" which is the most usual abnormal type, like a pear extruded on one side.

Our attitude was kept in these experiments and observations was limited in the following manner only the physico-chemical considerations were permited as basis of scientific conclusion, while hypothetical and biological assumptions were excluded.

To know the abnormalities is the base for knowledge of the normalities. Since pearls are produced in living organism, they are not only consisted of large amount of Calcium Carbonate crystals, but aiso contain some amounts of organic substances commonly named "conchiolin," a kind of protein. The conchiolin was first reported by FrEMY (1), and then studied by ScholossBerGER - (2), VOIT (3) WETzEL (4) and FRIZA (5). It was considered a kind of albuminoid, but there still remained many problems unsolved.

* Report of the Nippon Institute for Scientific Research on Pearls, No. 20.

Publ. Seto Mar. Biol, Lab., II (2), 1952. (Article 20) 
Recently, our co-worker Dr. TANAKA and others have determined its albuminoid nature (6).

The differences of structure, distribution and properties of conchiolin layers must have an important infuence upon the formation of $\mathrm{CaCO}_{3}$ crystals.

In this study, we endeavoured to discover the properties of the proteins in the abnormal layers.

\section{EXPERIMENTS AND RESULTS}

\section{Experiment 1. Protein content in appearance.}

The protein contents were determined from the decalcified residues but not from the burning residues. Protein content in volume was calculated from specific gravities (7). The results obtained are shown in Table 1.

Although these results are a rough estimate, the protein contents were higher than those secured by burning methods (14). Therefor, a considerable amount of protein will be observed in the layer.

Table 1. The residues of organic substances decalcified using $3 \%$ HCL solution.

(sp. gr. $2.9(1))$

\begin{tabular}{ccccc}
\hline & $\begin{array}{c}\text { Gr. used } \\
\text { pearl piese }\end{array}$ & $\begin{array}{c}\text { Gr. of dry residuss } \\
\text { after decalciried }\end{array}$ & $\begin{array}{c}\text { Ratios in } \\
\text { org. subst. } \\
\text { per to tal gr. }\end{array}$ & $\begin{array}{c}\text { Calculated } \\
\text { volume of } \\
\text { protein }\end{array}$ \\
\hline 1 & 0.3700 & 0.0521 & $14.0 \%$ & $33.6 \%$ \\
2 & 0.5420 & 0.0773 & $14.2 \%$ & $34.0 \%$ \\
Mean & & & $14.1 \%$ & $33.8 \%$ \\
\hline
\end{tabular}

Two supplemental experiments were made for direct observation of proteins.

a. Microscopical studies of decalcified conchio:in residues with paraffin sectionings and double stainings.

The method was the same as used generally in biological studies; the samples were sectioned by $20 \mu$, and then stained with eosin and aniline blue.

They were stained out in layer structures, and the staining properties of the conchiolin were found to differ in the abnormal parts.

b. Decalcifyings and siainings under the polarization microscope.

The samples were ground into $20 \mu$ slices which are generally used in mineralogical observations. Stainings and decalcifyings were the same as 
the experiment a. The sharp bi-refringence differenciated the $\mathrm{CaCO}_{3}$ crystals from conchiolins.

Normal pearl layers were found as a concentrically built up films and as faintly double-stained layer.

The abnormal part in the pearl layer contained various structures of conchiolin such as a mass, grains, fibers, cylinders and thick colored layers. They were classified in two parts, namely acidophilic heavy stained portions and unstainable colored portions. The former had thick $\mathrm{CaCO}_{3}$ crystal layers but the latter contained on the contrary no crystals. Thus, it seems that conchiolins may be well described merely in terms of protein in the following sections.

Experiment 2. The interrelation of $\mathrm{CaCO}_{3}$ crystals and abnormal protein layers.

Samples were ground into $20 \mu$, and sectioned with the plane containing the center of the nucleus and the top of the extruded abnormal part.

The polarization microscope was also used as well as in the previous observation. Proteins had no bi refringence, while the crystals showed a sharp bi-refringence. The abnormal structures are shown in Fig. 1. In the Fig, 1, (1) is the normal pearl layer and $(2-11)$ are the abnormal layers. Moreover the latter was divided into the large crystal layers $(2-5)$ and no crystal layers $(8-9)$. (2-4) are the thick crystal layers which contain a radial protein structure, (5) is a random crystal layer, and $(6-7)$ are independent giant crystals.

The proteins in these abnormal structures were also stained eosinophilic as reported above.

No crystal layers $(8-10)$ consisted of colored organic substances of yellow, brown and black.

These substances were unstainable. (ref. Photo. (1) (3) and (7))

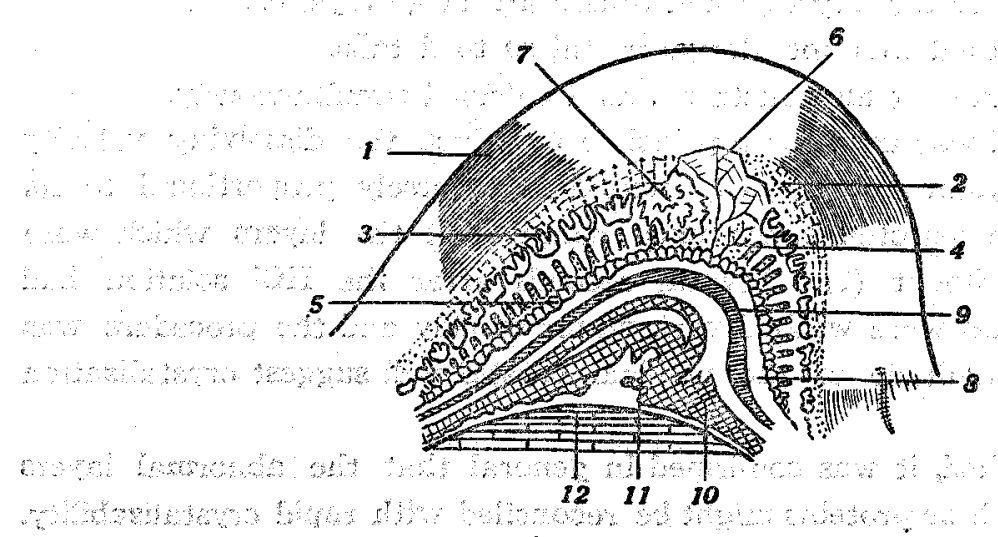

Fig. 1. Section of pearl layer, showing the abnomal structure. For further explanaion see text. 
Experiment 3. The bulk and the axiality of the crystals in the abnormal layers.

The axiality of each crystal was determined by the interference bands. Contrary to our expectations in all the cases it was found to be diaxial (ref. Table 2).

Table 2. Axiality of the abnormal crystais.

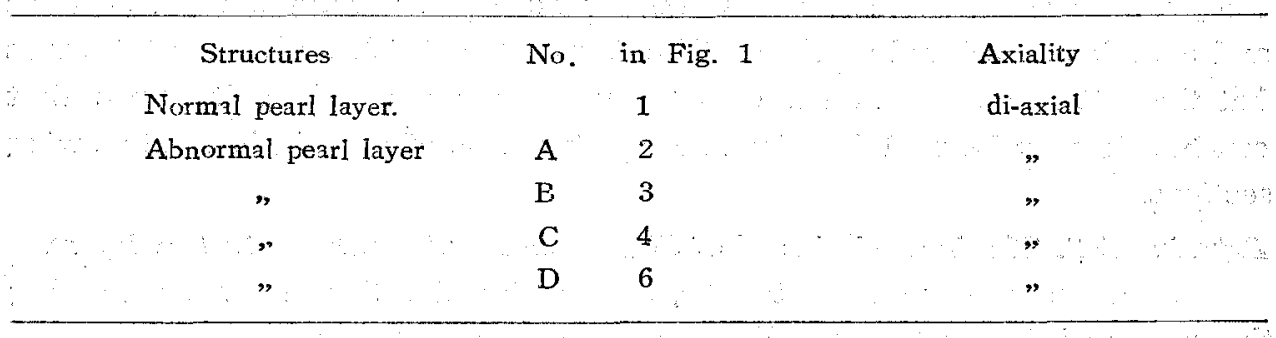

The bulk of the crystals showed us evidences of development velocity of crystals.

The results were obtained by the following three methods.

a) The thickness of the continuous layers tangentially to the nuclear surface $\because$ as measured.

It was easily imaginable that these should have developed simultaneously. They showed distinctive thickness in the abnormal part (Fig. 1).

b) The bulk of the crystals can be observed with bi-refringence by rotated nicols. Oriented or random arrangement of crystals are differenciated by this method.

In Fig. 1 , the crystals in $1,2,3$ and 4 are arranged in certain directions, while 5, 6 and 7 contain a randomly arranged crystal or an independent large crystal. 1 and 5 are fine crystals and others are large crystals.

But this method was not always useful as to details.

c) The zone containing all structure was decalcified simultaneously.

This method was used for a principle by which the dissolving velocity of the $\mathrm{CaCO}_{3}$ crystal in $3 \% \mathrm{HCl}$ solution is inversely proportional to its bulk surface. The selected zones must contain all the layers which were classified in experiment (1). Several seconds after the HCl solution had been added, samples were washed with water quickly and the procedure was stopped. The magnitude of the residual crystal will suggest crystalization velocity.

By this method, it was confirmed in general that the abnormal layers containing eosinophilic proteins might be reconciled with rapid crystalizability. (ref. Photo. 2, 4 and 5) 


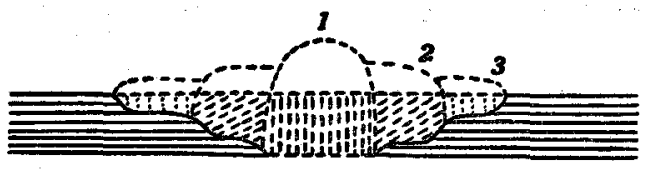

Fig 2. Method of decalcification by $\mathrm{HCl}$ solution

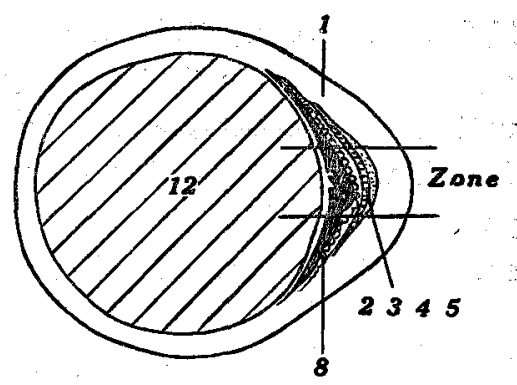

Fig. 3. Tutal section of baroque pearl

Experiment 4. Structures of the normal pearl layer.

It is difficult to prepare the samples under $20 \mu$ thickness. In order to prepare the $1-0.5 \mu$ sample which correspond to the height of unit pearl layer (7) (8), the selected normal pearl layer in the $20 \mu$ sample was decalcified by a method shown in Fig. 2. At first, a drop of $3 \%$ HCL solution is mounted at a position 1, and a few seconds later the mounted $\mathrm{HCl}$ solution is spread concentrically to the region 2 and so forth.

At the part 1 in Fig. 2, the separated protein layers were clearly shown (ref. Photo. 6). At the part 2, the separated $\mathrm{CaCO}_{3}$ crystal layers were observed (see Photo. 5 and 6). But they were not always equal as to their thickness.

The mean values of several layers showed us that the thickness of unit layer was about $450-500 m \mu$, so that the crystaline layers were estimated to be of a thickness of about $200-300 m \mu$.

\section{CONCLUSION}

(1) The protein content from the decalcifying residue was higher than that resulting the burning method. It was estimated roughly to be about $14 \%$ in weight and about $30 \%$ in volume.

(2) At the central region of the abnormal part, the layers containing the organic substances were differenciated in order from the nuclear surface as such a layer of colored organic substances $(8-10)$, layers containing eosinophilic protein structures arranged radially against the nuclear surface $(2,3,4$ and 5) and the layers stained faintly with both dyes.

(3) No crystals were found in the first layer, thick crystal layers in the second and oriented thin crystal layers in the last indicated by bi-refringence. (4) The eosinophilic layers consisted mainly of thick oriented crystal layers. 
Sometimes. we observed random crystal layers and giant crystals. The higher rate of crystalizability in these layers was suggested by three methods. (5) It was shown that the crystals must be of the aragonite form by observation of their interference bands.

(6) It was confirmed by the stepwise decalcifying method that the normal pearl layers consist of alternative layers of proteins and crystals, which are estimated at about $200-300 \mathrm{m \mu}$.

\section{DISCUSSION}

In appearance, there are found a considerable amount of organic substance in the pearl layer. The organic substances have been found about $30 \%$ in volume by calculating from the specific gravity of protein, $\mathrm{CaCO}_{3}$ and the pearl $\left(8,8^{\prime}\right)$. The $\mathrm{Ca}$ crystal protein ratio in weight was $17 / 3$ and that in volume $7 / 3$. Concerning studies of the baroque pearls almost nobody reported.

But it is interesting and important to study the mechanism of formation of the pearl layer. The innermost layer consisted of the colored organic substance, the abnormal center was unstainable and moreover no crystals were found there although these layers were very thick and complex.

The structural protein in the next abnormal layers was stained by acidic dyes such as eosine. The polymorphic structural protein in this layer may be considered as a basic substance.

Surprisingly, we found a large member of crystals produced in this layer.

Perhaps, the development velocity may be as rapid as a hundred times more than that of the normal layers. May these proteins and $\mathrm{CaCO}_{3}$ crystals be in basic correspondence?

It is supposed that the normal pearl layer contains a neutral protein, because it was stained faintly with both acidic and basic dyes.

The alternative thin layers of proteins and crystals in the normal part suggest to us a low development velocity of the crystals. K. Taramoto (9) had pointed out in his study of the wounded tissue that acidosis occurred in the first stage, followed an alkalosis, and then the wound was healed.

In the case of some molluscs, K. INAHARA (10) suggested that the secreted substances from the mantle cut into small pieces were stained first by Sudan III, eosine in the next phase and then in the last phase stained faintly by Malachite green. It can be imagined from these facts that the operation of inserting the nucleus may probably raise an abnormalities in an analogous process.

While the Calcite crystalizes in ordinary temperature, the aragonite appears at higher temperatures. It is conceivable that the other factors lexcept

$$
-296=
$$


the proteins) can have no influence upon the crystalization of the $\mathrm{CaCO}_{3}$ in aragonite form in this case.

The mechanism of the rapid crystalization in the basic protein layers has to be studied further in more details.

It should be remarked that the normal pearl layer may be produced slowly in the normal biological condition. The alternative deposition of protein and $\mathrm{CaCO}_{3}$ about $200-300 m \mu$, though it is a rough estimation, shall be supported by the facts reported by I. Honjo (11), in which the shell was closed by light radiation and by S. MoRI (12) in which activity was increased in twilight.

Here, the Ca protein ratio in the pearl layer was $17 / 3$ in weight in this study. That of secreted mucoproteins was reported about $2 / 3$ or $1 / 2$ (13). The ratio in the muscle of some molluscs was less. (14).

The calcium detection in the mantle tissue by Ojima (15) has shown that the Ca-oxalate crystals are found only in the peripheral portion.

Matsur had always insisted that the oceanographic conditions, the $\mathrm{Ca}$ content of the sea water, would be important on calcification of shells.

The $\mathrm{Ca}$ content of the sea water is almost equal to the maximum solubility of the $\mathrm{CaCO}_{3}$. If $\mathrm{CO}_{2}$ were produced by respiration or other factor in epithelial tissues, the $\mathrm{CaCO}_{3}$ precipitation would be enabled to take place immediately.

Although it is not clearly decided, the protein secretion and $\mathrm{Ca}$ deposition might be to interrelated with each other. In these respects the mechanism in detail should be analysed further.

We wish to express our gratitude for Dr. HAYAse who has offered us many kind suggestions and conveniences, and also to the members of Seto Marine Biological Station of Kyoto University.

\section{SUMMARY}

1. Correlations between protein and $\mathrm{CaCO}_{3}$ crystals in the baroque pearl layer were studied with the polarization microscope and double staining.

2. The protein content was determined froin the decalcifying residue. The result showed us a higher protein contents than that of a burning method. In appearance, the protein contents were estimated at about $30 \%$ in volume.

3. There were observed three sorts of protein layer; the colored unstainable organic layer, the basic protein layer and the pearl layer in the abnormal pearl.

4. The first layer could not be stained at all, the second stained with 
acidic dyes and the third stained faintly by both acidic and basic dyes. Morphologically they were characterized as eddied, radial and thinly concentric.

5. No crystals developed at first. An extremely thick crystalization occured in the second, and in the third, the proteins and the $\mathrm{CaCO}_{3}$ crystals were found as alternative layers.

In the conoscopical observation, the interference band of each crystal had indicated diaxial form of aragonite.

The cause of abnormality in the baroque pearl depends upon both the basic and the unstained layers. It was supposed that these layers were probably occurred by the operation in which the nuclei were inserted.

\section{LITERATURE}

(1) Fremy, E. 1855. Ann. de Chem. et Phys., ser. 4, 1, 43, 96.

(2) Schlossberger, J. 1859. Ann. de Chem. et Pharmacie, 18, 99.

(3) VoIT, C. 1860. Z. f. Wiss. Zool. 10, 470.

(4) Wetzel, G. 1899. Z. f. Wiss. Physiol. Chem. 13, 113.

(5) FRIZA, F. 1932. Biochem. Zeit, 249, 29.

(6) TANAKA, S., HATANO, H. and others. J. chem. Soc. Japan. (Under print).

(7) UCHIDA, Y. and UEDA, S. 1949. Seiri-Seitai, 1, 3, 171.

(8) OMORI, K. 1948. Geographical Magazine, 54, 631.

(8') 1947. Kagaku Asahi, 7, 34,

(9) ТАКАмото, K. 1950. Seiri-Seitai, 4, 1-2, 59.

(10) INAHARA, K. Unpublished.

(11) HONJO, I. 1948. Seiri.Seitai, 2, 2, 57.

(12) MORI, S. 1948. Jap. J. Malac. 15, 1-4, 46.

(13) TANAKA, S. and HATANO, H. Unpublished.

(14) OGUSHI, J. 1938. Studies of Pear's.

(15) OjIMA, Y. 1952. Cytologia, 17, 1. 


\section{EXPLANATION OF PLATE XIII}

Fig. 1. The sample ground to $20 \mu$ Experiment 1.

A. Normal pearl layer. B-D. Abnormal layers. G. Nucleus. with ordinary microscope.

Fig. 2. Enlarged photograph of the abnormal region circulated in Fig. 1.

B. Irregular mass. C. Fiber. D. Cylinder. E. and F. Colored organic substances.

Fig. 3. Some abnormal structures of eosinophilic protein layers.

Fig. 4. Eosinophilic protein layers observed with the polarization microscope.

Fig. 5. Simultaneous decalcification of the zone contained every structure.

Fig. 6. Stepwise decalcification of the normal pearl layers. Upward arrow shows the separated protein layers and the downward the layer structure of the crystals in the normal pearl layers.

Fig. 7. Double staining. Upward half is not decalcified and downward half was decalcified. Heavily stained portion is the eosinophilic protein layers. $A$ and $\mathbf{E}$ were not stained. 
Publ. Seto Mar. Biol. Lab., II, 2 (1952)

PLATE XIII
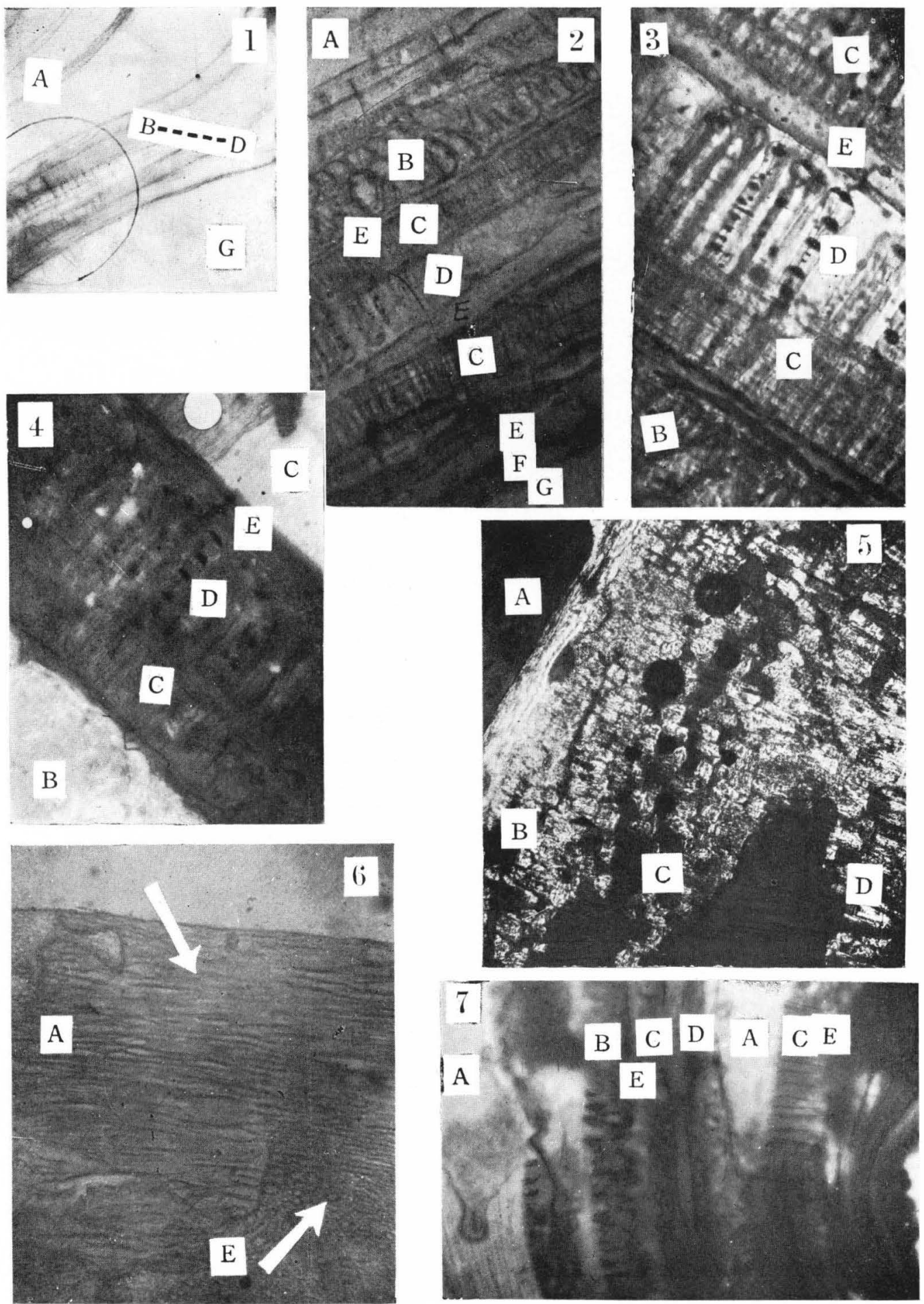

Y. Matsui \& T. Hirota: Studies on the Formation of Pearls. (I) 